subject to simple mathematical laws. On the industrial side, a series of researches revolutionized the maturation of beer. It is forty years since Stern substituted metal tanks with single-feed cylinders in the racking room instead of the old single wooden casks; and his method has now become standard practice. Many technical processes were influenced by him, from the better use of fuel in breweries to the bottling of beer and its dispatch overseas so that "Bass" should arrive in perfect condition in diverse climates. Incidentally, he, under O'Sullivan, brewed the famous King's Ale of 1902.

Stern's brewery was a happy place. He was not only a master brewer, but also had happy relations with his staff, and took a personal interest in them and their families. He was a man of wide interests, and although he retired early, he never lost contact with scientific affairs.

He had a very happy married life, saddened only by his wife's death last year. He leaves seven children, all of whom went to universities, four of them following scientific careers; his eldest grandchild is about to enter Cambridge to read science.

\section{Mr. Harold Picton}

Harold Picton, who died on March 21 in his eighty-ninth year, will be remembered for his con. tributions to science, education and international understanding.

Picton was a son of the Rev. J. A. Picton, Unitarian minister and M.P. for Leicester, and grandson of Sir James Picton, of Liverpool. After graduating at University College, London, he worked in Sir William Ramsay's laboratory. With S. E. Linder he published a series of papers on colloidal solutions. Sols of arsenious sulphide were prepared in various grades down to one in which the submicroscopic particles passed through porous pot and diffused, yet still scattered light, giving the Tyndall effect. Picton and Linder were the first to show the migration of such particles in an electric field, the arsenious sulphide moving to the anode and ferric hydroxide to the cathode. They studied the precipitation of these sols by electrolytes and showed the presence of the positive ion in the precipitated arsenious sulphide. The efficiency of the electrolyte as coagulator was also related to the charge on the positive ion. This is known as the Hardy-Schulze Law, but, as Prof. W. C. McC. Lewis wrote, it "might perhaps more legitimately be known as the Schulze-Linder-PictonHardy Law". This work undoubtedly laid the foundation of much of the modern view of suspensoid colloidal systems.

In 1900, after a few years as science master at Parmiter's School, Picton joined his friend, the Rev. J. E. Bennett, who had opened a small residential school, Clacton College, and shortly afterwards he succeeded him as headmaster. 'This was a remarkable school which anticipated many modern trends in education. A family spirit was developed both in and out of the classroom. Discipline was strict but kindly, and was based on rules laid down by an elected school council. The physical, mental and spiritual aspects of personality were provided for in a well-balanced whole. Games were played but were not over-emphasized, and boys were encouraged to take up other interests such as gardening, photography, and the study of church architecture and of prehistoric remains. A number of worked flints and mammalian bones and teeth were collected from the Pleistocene deposit on the Clacton foreshore and this section of the school museum was afterwards presented to Charterhouse School.

From his mother (née Jessie C. Williams), who was brought up in Hamburg, Picton acquired a deep love of Germany. From 1914 onwards he strove to promote a better understanding between the Germans and the British. In five books published between 1918 and 1948 and many other writings he stressed the better elements in German life and culture. His "Early German Art and its Origins" (1939) was an important work. For six years he lived near Berlin but returned to England in 1934 after the rise of Hitler. From that time he exposed the horrors and dangers of the Nazi dictatorship; but always insisted that the whole German nation should not be condemned for the crimes of the Nazis. He worked untiringly to help refugees from Germany.

Harold Picton was a man of vigorous and manysided personality to whom men were more important than systems. He had a genius for friendship and he gained the affection as well as the admiration of his pupils, who will never forget the debt they owe him. He did not marry but adopted a son, who survives him.

G. M. Bennett.

\section{Dr. Harry J. Deuel, jun.}

Dr. Harry J. Deuel, jun., whose death at the age of fifty-eight occurred on April 17, had been an active force in the field of nutrition for more than a quarter of a century, his major interest being the biochemistry of lipids. His group at the University of Southern California has established a vast amount of biological data on the digestibility of fats and the lipid composition of the tissues of different animals under varying experimental conditions. This quantitative information has been, and will continue to be, of great value to innumerable workers in this field.

It is not only as an accumulator of facts that Dr. Deuel will be remembered; he also made notable contributions to advancing knowledge, especially in connexion with the composition of cerebrosides, the conversion of carotene to vitamin $A$, the nutritional importance of dietary fat and the effect of hormones on lipid metabolism. He had a wide knowledge and interest in all work in the lipid field, and many will recall happy hours of argument and discussion in which he took a leading part. This width of experience found expression during the past few years in his writing "The Lipids; their Chemistry and Biochemistry", two volumes of which have already been published. The third and last volume was nearing completion at the end of last year. This work is likely to become established as a standard work in this field-a fitting memorial to its author.

Harry Deuel took great delight in meeting people. As a Fulbright Fellow at Cambridge during the past year, he was able to renew many old friendships and to make many new ones. He carried through an active programme of lectures and visits, both in Britain and on the Continent. Those who had the privilege of meeting or hearing him during this past year will find inspiration, not only from the scientific contributions he made on many occasions, but also from his immense courage and fortitude. He was a man that so many of us were happy and proud to have known.
A. C. Frazer 